\title{
Medullary carcinoma of the thyroid with parathyroid adenoma and hypercalcaemia
}

\author{
J. B. MacGILLIVRAY AND C. J. B. ANDERSON \\ From the Department of Pathology, Maryfield Hospital, Dundee, and Arbroath Infirmary
}

SYNOPSIS A patient with hyperparathyroidism due to a parathyroid adenoma was found to have metastatic medullary carcinoma in lymph nodes close to the thyroid gland. The finding of normal calcitonin and parathormone concentrations after removal of the adenoma suggested that the parathyroid lesion was not the result of the hypocalcaemic action of calcitonin produced by the tumour in the thyroid.

Seventeen other examples of the association between medullary carcinoma and parathyroid enlargement are briefly reviewed.

The pathogenesis of the parathyroid lesions is discussed, and it is suggested that some may be caused by the hypocalcaemic action of calcitonin, while others may be part of a syndrome of multiple endocrine adenomatosis.

Medullary carcinoma is a special form of thyroid carcinoma characterized by the presence of amyloid in the tumour tissue (Williams, Brown, and Doniach, 1966) and by the production of calcitonin (Cunliffe, Black, Hall, Johnston, Hudgson, Shuster, Gudmundsson, Joplin, Williams, Woodhouse, Galante, and MacIntyre, 1968). Medullary carcinoma may be familial and is sometimes associated with phaeochromocytoma and multiple mucosal neuromata (Williams et al, 1966).

In 17 cases taken from the literature, parathyroid adenoma or hyperplasia has been an additional feature (Table I) and in six of these there was evidence of hypercalcaemia (Table I, cases 12, 13, $14,15,16,17)$.

We wish to report a further example of the association between medullary carcinoma and parathyroid adenoma in a patient who presented with hypercalcaemia and nephrocalcinosis.

\section{Case Report}

A 52-year-old woman was seen in 1967 , complaining of two episodes of renal pain and the passage of small renal calculi. An intravenous pyelogram showed calcification in the medullary pyramids. The serum calcium was $11.6 \mathrm{mg} / 100 \mathrm{ml}$ (normal 8.8$10.6 \mathrm{mg} / 100 \mathrm{ml}$ ) and the phosphorus $2.0 \mathrm{mg} / 100 \mathrm{ml}$

Received for publication 26 May 1971. (normal $2 \cdot 5-4 \cdot 5 \mathrm{mg} / 100 \mathrm{ml}$ ). Inpatient investigation was advised, but the patient, who was by then feeling well, declined.

A year later she was seen again having passed further stones. At this time the serum calcium was $9.4 \mathrm{mg} / 100 \mathrm{ml}$ and the phosphorus $3.1 \mathrm{mg} / 100 \mathrm{ml}$.

Early in 1970 she began to complain of extreme lassitude, tiredness, and backache. Radiographs in June 1970 again showed calcification in both kidneys. No definite phalangeal erosions were seen, but the skull showed irregular mottling and multiple translucent areas. The serum calcium was now $12.9 \mathrm{mg} /$ $100 \mathrm{ml}$ and the phosphorus $2 \cdot 1 \mathrm{mg} / 100 \mathrm{ml}$. A diagnosis of hyperparathyroidism was made and the neck was explored.

At operation an enlarged right superior parathyroid was identified and removed. The right lower parathyroid was not identified, but the left superior and left inferior parathyroids were not enlarged. The thyroid was nodular and a circumscribed nodule found in the lower pole of the left lobe was enucleated. Three small nodules lying close to the left lobe of the thyroid were also removed. They were thought to be lymph nodes, but due to the lack of frozen section facilities this could not be confirmed.

The postoperative course and convalescence were uneventful and six days after operation the serum calcium had fallen to $8.9 \mathrm{mg} / 100 \mathrm{ml}$. Since that time serum calcium and phosphorus estimations have always given results within the normal range. 


\begin{tabular}{|c|c|c|c|c|c|c|}
\hline $\begin{array}{l}\text { Case } \\
\text { No. }\end{array}$ & Author & $\begin{array}{l}\text { Age } \\
\text { and } \\
\text { Sex }\end{array}$ & Medullary Carcinoma & $\begin{array}{l}\text { Phaeochromo- } \\
\text { cytoma }\end{array}$ & Parathyroids & Comments \\
\hline \multicolumn{7}{|c|}{ Without Hypercalcaemia } \\
\hline 1 & $\begin{array}{l}\text { Freeman and Lindsay } \\
\text { (1965) }\end{array}$ & - & $\because$ & - & Adenoma & $\begin{array}{l}\text { Parathyroid lesion an incidental } \\
\text { finding }\end{array}$ \\
\hline 2 & $\begin{array}{l}\text { Ibanez, Cole, Russell, and } \\
\text { Clark (1967) }\end{array}$ & - & $\therefore$ & - & Adenoma & $\begin{array}{l}\text { Parathyroid lesion an incidental } \\
\text { finding }\end{array}$ \\
\hline 3 & Williams (1967) & $\begin{array}{l}M \\
54\end{array}$ & Widespread metastases & 一 & Hyperplastic & $\begin{array}{l}\text { Parathyroid lesion an incidental } \\
\text { finding }\end{array}$ \\
\hline 4 & $\begin{array}{l}\text { Gonzalez-Licea, Hart- } \\
\text { mann, and Yardley (1968) }\end{array}$ & - & +- & - & Hyperplastic & $\begin{array}{l}\text { Parathyroid lesion an incidental } \\
\text { finding }\end{array}$ \\
\hline 5 & $\begin{array}{l}\text { Gonzalez-Licea, Hart- } \\
\text { mann, and Yardley (1968) }\end{array}$ & - & $\therefore$ & - & Hyperplastic & $\begin{array}{l}\text { Parathyroid lesion an incidental } \\
\text { finding }\end{array}$ \\
\hline 6 & Sipple (1961) & $\begin{array}{l}\text { M } \\
33\end{array}$ & $\because-$ & + & $\begin{array}{l}\text { Nodular enlarge- } \\
\text { ment of } 1 \text { gland } \\
\text { ? adenoma }\end{array}$ & $\begin{array}{l}\text { Lesions all incidental necropsy } \\
\text { findings }\end{array}$ \\
\hline 7 & Cushman (1962) & $\begin{array}{l}M \\
55\end{array}$ & Widespread metastases & + & Adenoma & $\begin{array}{l}\text { Adenoma and phaeochromocytoma } \\
\text { found at necropsy } 25 \text { yr after cervical } \\
\text { nodes containing medullary } \\
\text { carcinoma removed }\end{array}$ \\
\hline 8 & Freeman and Lindsay & -- & ( & $\therefore$ & Adenoma & Adenoma an incidental finding \\
\hline 9 & $\begin{array}{l}\text { Moorhead, Caldwell, } \\
\text { Kelly, and Morales (1966) }\end{array}$ & 一 & Widespread metastases & $\cdots$ & $\begin{array}{l}\text { Multiple } \\
\text { adenomas }\end{array}$ & Also had Cushing's syndrome \\
\hline 10 & Urbanski (1967) & $\begin{array}{l}F \\
32\end{array}$ & -.. & & Adenoma & $\begin{array}{l}\text { Nodular thyroid containing medul- } \\
\text { lary carcinoma found on routine } \\
\text { medical; } 5 \text { yr later bilateral phaeo- } \\
\text { chromocytomas removed }\end{array}$ \\
\hline 11 & $\begin{array}{l}\text { Williams, Morales, and } \\
\text { Horn (1968) }\end{array}$ & $\begin{array}{l}F \\
46\end{array}$ & Widespread metastases & $\therefore$ & Adenoma & Also had Cushing's syndrome \\
\hline \multicolumn{7}{|c|}{ With Hypercalcaemia } \\
\hline 12 & $\begin{array}{l}\text { Moertel, Beahrs, Woolner, } \\
\text { and Tyce (1965) }\end{array}$ & $\begin{array}{l}F \\
66\end{array}$ & $\begin{array}{l}\text { Probably medullary } \\
\text { carcinoma but no } \\
\text { amyloid }\end{array}$ & - & Adenoma & $\begin{array}{l}\text { Mass in neck; thyroidectomy per- } \\
\text { formed; thought to have hyper- } \\
\text { parathyroidism but data incomplete: } \\
\text { developed metastases and carcinoid } \\
\text { syndrome }\end{array}$ \\
\hline 13 & $\begin{array}{l}\text { Steiner, Goodman, and } \\
\text { Powers (1968) }\end{array}$ & $\begin{array}{l}M \\
17\end{array}$ & $\ldots$ & - & $\begin{array}{l}\text { Chief cell } \\
\text { hyperplasia }\end{array}$ & $\begin{array}{l}\text { Hyperparathyroidism found on } \\
\text { routine examination; hard nodule in } \\
\text { left lobe of thyroid proved to be } \\
\text { medullary carcinoma }\end{array}$ \\
\hline 14 & $\begin{array}{l}\text { Finegold and Haddad } \\
\text { (1963) }\end{array}$ & $\begin{array}{l}M \\
27\end{array}$ & $\begin{array}{l}\text { Multiple bony } \\
\text { metastases }\end{array}$ & $\div$ & Two adenomas & $\begin{array}{l}\text { Hypercalcaemia and nephrocalcino- } \\
\text { sis; bilateral phaeochromocytomas } \\
\text { found at necropsy }\end{array}$ \\
\hline 15 & $\begin{array}{l}\text { Manning, Molnar, Black, } \\
\text { Priestley, and Woolner } \\
\text { (1963) }\end{array}$ & $\begin{array}{l}F \\
18\end{array}$ & - & $\therefore$ & $\begin{array}{l}\text { Three enlarged } \\
\text { due to adenoma } \\
\text { or chief cell } \\
\text { hyperplasia }\end{array}$ & $\begin{array}{l}1954 \text { bilateral phaeochromocytomas } \\
\text { removed; } 1961 \text { hypercalcaemia and } \\
\text { nephrocalcinosis; at parathyroid- } \\
\text { ectomy enlarged thyroid also } \\
\text { removed }\end{array}$ \\
\hline 16 & Sarosi and Doe (1968) & $\begin{array}{l}M \\
54\end{array}$ & $\cdots$ & $\therefore$ & Two adenomas & $\begin{array}{l}\text { Left phaeochromocytoma removed; } \\
\text { nodular thyroid noted and thyroid- } \\
\text { ectomy performed; serum calcium } \\
\text { raised; neck re-explored and } \\
\text { adenomas removed }\end{array}$ \\
\hline 17 & $\begin{array}{l}\text { Steiner, Goodman, and } \\
\text { Powers (1968) }\end{array}$ & $\begin{array}{l}F \\
36\end{array}$ & & $\div$ & $\begin{array}{l}\text { Chief cell } \\
\text { hyperplasia }\end{array}$ & $\begin{array}{l}\text { Bilateral phaeochromocytomas re- } \\
\text { moved; hyperparathyroidism diag- } \\
\text { nosed; medullary carcinoma found } \\
\text { when neck explored }\end{array}$ \\
\hline
\end{tabular}

Table I Medullary carcinoma, phaeochromocytoma, and parathyroid adenoma or hyperplasia

\section{PATHOLOGY}

The enlarged parathyroid measured $3.5 \times 2.5 \mathrm{~cm}$ and contained a cyst $1.8 \mathrm{~cm}$ diameter. It was made up of chief cells and a smaller number of oxyphil cells. There was an abundant oedematous stroma, an acinar pattern in many areas, and no sign of any rim of normal parathyroid gland (Fig. 1).

In view of the finding of other macroscopically normal parathyroids, it was considered that the lesion was probably an adenoma.

The three nodules were lymph nodes, each about $8 \mathrm{~mm}$ in diameter. All of them were extensively replaced by medullary carcinoma containing abundant amyloid which showed characteristic dichroism in sections stained with Congo red examined between crossed polaroids. 


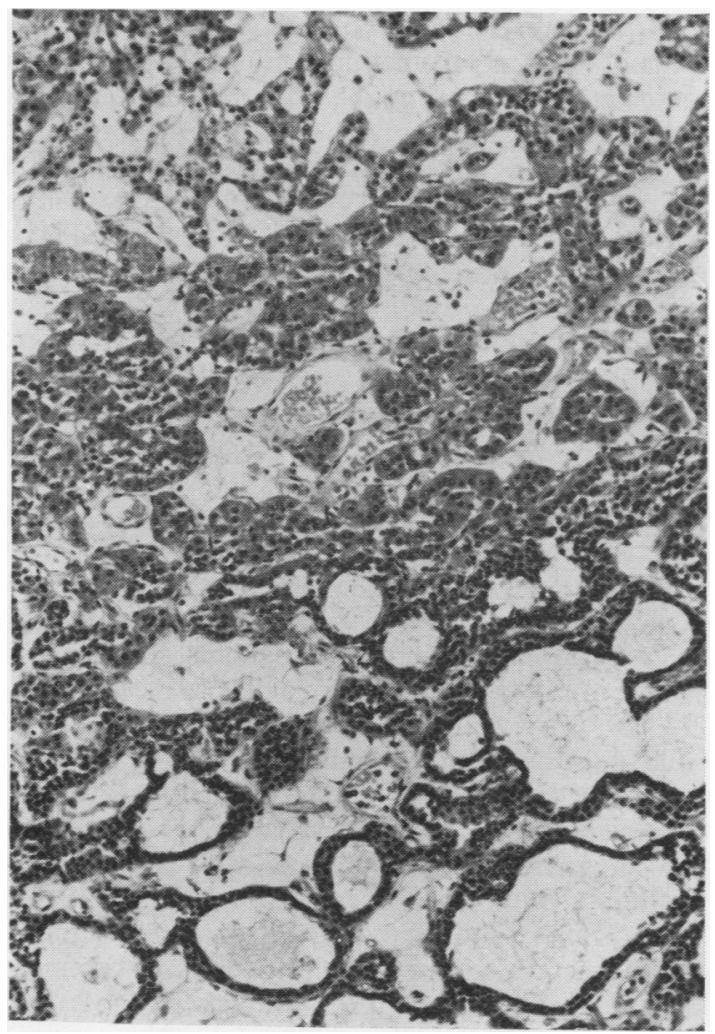

Fig. 1 Parathyroid adenoma with oedematous stroma showing oxyphil cells (above) and chief cells forming dilated acini (below). Haematoxylin and eosin $\times 84$.

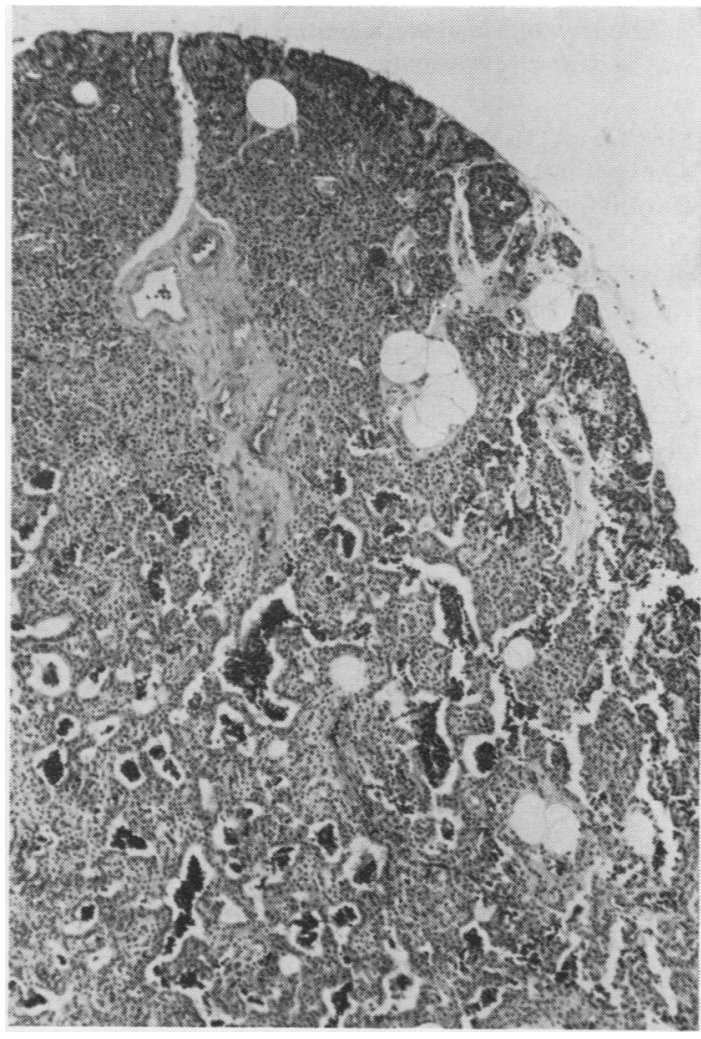

Fig. 3 Biopsy from left superior parathyroid consisting of chief cells, in places forming acini and occasional fat spaces. Haematoxylin and eosin $\times 120$.

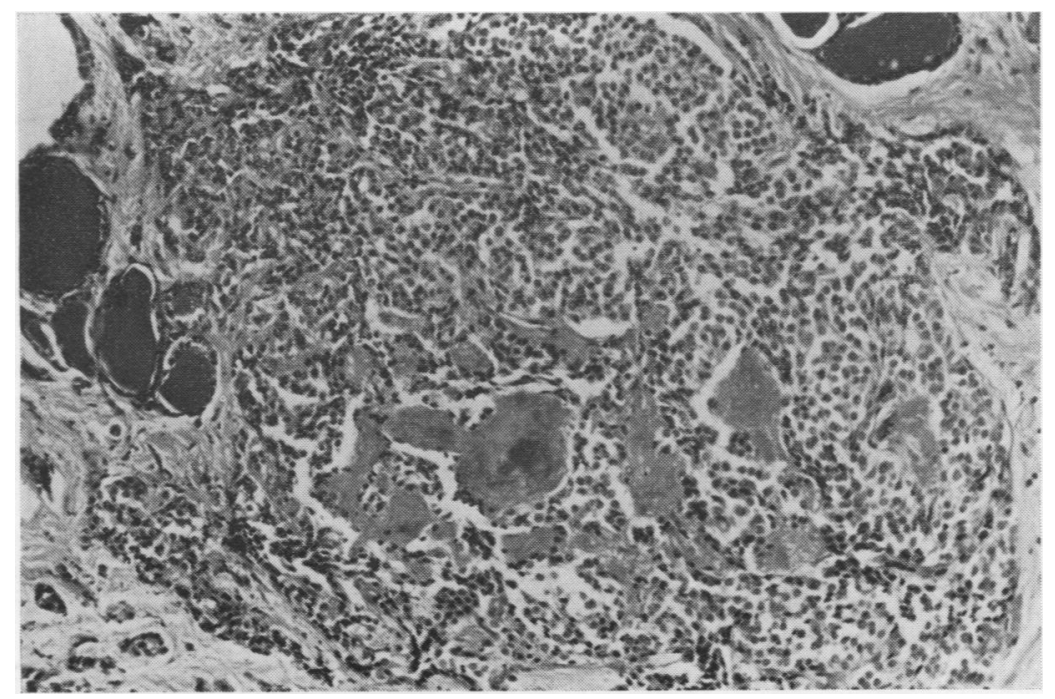

Fig. 2 Medullary carcinoma in left lobe of thyroid. Amyloid deposits amongst uniform darkly staining cells and adjacent thyroid follicles. Haematoxylin and eosin $\times 120$. 
The thyroid lesion measured $1.5 \mathrm{~cm}$ diameter and was a well circumscribed adenomatous nodule.

\section{FURTHER INVESTIGATION AND TREATMENT}

The patient did not have any mucosal neuromata. Enquiry revealed a sister who was hypothyroid but no other family history of endocrine disorders. The plasma calcitonin estimated by bioassay was not raised (Professor I. MacIntyre). The parathormone concentrations estimated by radioimmunoassay (Dr R. M. Buckle) in two samples of plasma were 0.26 and $0.15 \mathrm{ng} / \mathrm{ml}$ (normal $0 \cdot 30-<0 \cdot 1 \mathrm{ng} / \mathrm{ml}$ ). Urinary excretion of 5 hydroxyindoles and of vanillyl mandelic acid was not increased.

We concluded that the thyroid was likely to be the site of a medullary carcinoma and that thyroidectomy should be performed.

When the neck was re-explored two months after the original operation the thyroid could not be identified and removed because of marked induration in the surrounding tissues due to the previous surgery, but a further lymph node containing medullary carcinoma was excised. Six months later when the induration had subsided total thyroidectomy was successfully performed and a biopsy taken from the left superior parathyroid which was not enlarged.

\section{PATHOLOGY}

The thyroid weighed $30 \mathrm{~g}$. The right lobe contained an adenomatous nodule $8 \mathrm{~mm}$ in diameter. In the centre of the left lobe there was an ill defined, whitish area $6 \mathrm{~mm}$ in diameter. Microscopy showed this to be a medullary carcinoma containing a mass of amyloid in the centre of the tumour (Fig. 2). The biopsy of the left superior parathyroid did not show any microscopic evidence of hyperplasia (Fig. 3).

\section{Discussion}

Black and Haff (1970) have stressed the difficulty in distinguishing between parathyroid adenoma and chief cell hyperplasia. In our case the normal parathormone and calcium concentrations after the removal of the enlarged gland and the subsequent identification of normal parathyroid by light microscopy makes it unlikely that more than one abnormal gland was present.

When calcitonin levels have been estimated in patients with clinical evidence of medullary carcinoma they have almost always been elevated (Tashjian, Howland, Melvin, and Hill, 1970; Galante, 1971). It was surprising to find that in our patient the plasma calcitonin was not raised at a time when medullary carcinoma was present in the thyroid and in a lymph node, and suggests that certain occult tumours may be hormonally inactive.
The occurrence of two rare lesions in the same $\frac{\text { o }}{.}$ patient suggests something more than a chance $\vec{F}$ association and two possibilities may be considered.

Hypocalcaemia has been reported in patients with medullary carcinoma (Melvin and Tashjian, 1968; $\frac{\overline{0}}{\bar{\omega}}$ McDermott and Hart, 1970). Melvin and Tashjian $\frac{\sigma}{\vec{D}}$ (1968) found that the plasma of their patient con- $\propto$ tained high concentrations of calcitonin and para- $\%$ thormone. These findings, and the reports of para- $\vec{\circ}$ thyroid adenoma or hyperplasia in other cases of medullary carcinoma, suggest that the hypocalcaemic $\vec{\omega}$ effect of calcitonin produced by the tumour may stimulate parathormone production and cause? parathyroid enlargement.

The presence of bony secondaries might account 0 for the hypercalcaemia in the case reported by of Finegold and Haddad (1963) (Table I, case 14). $\overrightarrow{\mathrm{O}}$ Calcitonin and parathormone estimations were not $\stackrel{9}{2}$ performed in the other five patients shown in the $\overrightarrow{ }$ Table who had hypercalcaemia (Table I, cases 12, 13,

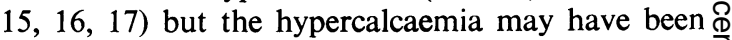
due to the development of an autonomous lesion in a $\frac{3}{\square}$ chronically stimulated gland as sometimes occurs in $\stackrel{\Phi}{\simeq}$ the secondary hyperparathyroidism associated with $\vec{\oplus}$ the malabsorption syndrome and chronic renal failure (Davies, Dent, and Watson, 1968).

Cushing's syndrome and the carcinoid syndrome have been associated with medullary carcinoma (Table I, cases 9, 11, 12). Williams, Morales, and Horn (1968) stress the close relationship between $\frac{\mathscr{Q}}{\varnothing}$ medullary carcinoma, certain thymic tumours, oat $\cong$ cell carcinoma, and carcinoid tumours, all of which $\overrightarrow{\underline{0}}$ may produce a variety of peptide hormones. Weichert (1970) suggests that cells in these tumours with the capacity to form peptide hormones have a neural crest origin in common with similar neuroendocrine cells which migrate into the endocrine: glands.

The syndrome of medullary carcinoma of thyroid, phaeochromocytoma, and multiple mucosal neuromata is considered by Weichert (1970) to be ao dysplasia of neural ectoderm and a type of multiple endocrine adenomatosis. This combination of lesionso is, however, thought to be a distinct genetic entity (Schimke, Hartmann, Prout, and Rimoin, 1968; N Steiner, Goodman, and Powers, 1968).

Parathyroid adenoma or chief cell hyperplasian may also form part of the syndrome (Steiner et al, $\mathrm{\omega}$ 1968; Weichert, 1970). Our finding of a normak plasma calcitonin level and a normal parathormone? level after removal of the adenoma supports thise view. It suggests that the adenoma was not a direct result of the presence of the medullary carcinoma, $\overline{0}$ unless it is postulated that the tumour at one time was producing calcitonin.

This appears to be the first report of calcitonin 
and parathormone concentrations in patients with hypercalcaemia and medullary carcinoma. Clearly until further studies are carried out the relation between medullary carcinoma and parathyroid adenoma and hyperplasia must remain uncertain.

We wish to thank Dr R. M. Buckle for determining the parathormone concentrations and Professor $\mathrm{I}$. MacIntyre for performing the calcitonin bioassay. Our thanks are also due to Professor E. D. Williams for examining histological material, to Dr C. R. Paterson for advice with the manuscript, and to Miss S. Nisbet for the photomicrographs.

\section{References}

Black, W. C., and Haff, R. C. (1970). The surgical pathology of parathyroid chief cell hyperplasia. Amer. J. clin. Path., 53, 565-579.

Cunliffe, W. J., Black, M. M., Hall, R., Johnston, I. D. A., Hudgson, P., Shuster, S., Gudmundsson, T. V., Joplin, G. F., Williams, E. D., Woodhouse, N. J. Y., Galante, L., and MacIntyre, I. (1968). A calcitonin-secreting thyroid carcinoma. Lancet, 2, 63-66.

Cushman, P., Jr. (1962). Familial endocrine tumours. Report of two unrelated kindred affected with pheochromocytomas, one also with multiple thyroid carcinomas. Amer. J. Med., 32, 352-360.

Davies, D. R., Dent, C. E., and Watson, L. (1968). Tertiary hyperparathyroidism. Brit. med. J., 3, 395-399.

Finegold, M. J., and Haddad, J. R. (1963). Multiple endocrine tumours. Report of an unusual triad in a family. Arch. Path. $76,449-455$

Freeman, D., and Lindsay, S. (1965). Medullary carcinoma of the thyroid gland: a clinicopathological study of 33 patients. Arch. Path., 80, 575-582.

Galante, L. (1971). Personal communication.

Gonzalez-Licea, A., Hartmann, W. H., and Yardley, J. H. (1968), Medullary carcinoma of the ithyroid. Ultrastructural evidence of its origin from the parafollicular cell and its possible relation to carcinoid tumors. Amer. J. clin. Path., 49, 512-520.

Ibanez, M. L., Cole, V. W., Russell, W. O., and Clark, R. L. (1967). Solid carcinoma of the thyroid gland. Analysis of 53 cases. Cancer (Philad.), 20, 706-723.

Manning, P. C., Jr., Molnar, G. D., Black, B. M., Priestley, J. T., and Woolner, L. B. (1963). Pheochromocytoma, hyperparathyroidism and thyroid carcinoma occurring coincidentally. Report of a case. New Engl. J. Med., 268, 68-72.

McDermott, F. T., and Hart. J. A. L. (1970). Medullary carcinoma of the thyroid with hypocalcaemia: clinical and ultrastructural observations. Brit. J. Surg., 57, 657-661.

Melvin, K. E. W., and Tashjian, A. H., Jr. (1968). The syndrome of excessive thyrocalcitonin produced by medullary carcinoma of the thyroid. Proc. nat. Acad. Sci. (Wash.), 59, 1216-1222.

Moertel, C. G., Beahrs, O. H., Woolner, L. B., and Tyce, G. M (1965). 'Malignant carcinoid syndrome' associated with noncarcinoid tumors. New Engl.J. Med., 273, 244-248.
Moorhead, E. L., Caldwell, J. R., Kelly, A. R., and Morales, A. R. (1966). The diagnosis of pheochromocytoma. Analysis of 26 cases. J. Amer. med. Ass., 196, 1107-1113.

Sarosi, G., and Doe, R. P. (1968). Familial occurrence of parathyroid adenomas, pheochromocytoma and medullary carcinoma of the thyroid with amyloid stroma. (Sipple's syndrome). Ann. intern. Med., 68, 1305-1309.

Schimke, R. N., Hartmann, W. H., Prout, T. E., and Rimoin, D. L. (1968). Syndrome of bilateral pheochromocytoma, medullary thyroid carcinoma and multiple neuromas. A possible regulatory defect in the differentiation of chromaffin tissue. New Engl. J. Med., 279, 1-7.

Sipple, J. H. (1961). The association of pheochromocytoma with carcinoma of the thyroid gland. Amer. J. Med., 31, 163-166.

Steiner, A. L., Goodman, A. D., and Powers, S. R. (1968). Study of a kindred with pheochromocytoma, medullary thyroid carcinoma, hyperparathyroidism and Cushing's disease: multiple endocrine neoplasia, type 2. Medicine (Baltimore), 47, 371-409.

Tashjian, A. H., Jr., Howland, B. G., Melvin, K. E. W., and Hill, C. S., Jr. (1970). Immunoassay of human calcitonin. Clinical measurement, relation to serum calcium and studies on patients with medullary carcinoma. New Engl. J. Med., 283, 890-895.

Urbanski, F. X. (1967). Medullary thyroid carcinoma, parathyroid adenoma, and bilateral pheochromocytoma. An unusual triad of endocrine tumors. J. chron. Dis., 20, 627-636.

Weichert, R. F., III. (1970). The neural ectodermal origin of the peptide secreting endocrine glands: a unifying concept for the etiology of multiple endocrine adenomatosis and the inappropriate secretion of peptide hormones by neoendocrine tumors. Amer. J. Med., 49, 232-241.

Williams, E. D. (1967). Medullary carcinoma of thyroid. In Symposium on the Thyroid Gland. J. clin. Path. Suppl. (Ass. Clin. Path.), 20, 395-398.

Williams, E. D., Brown, C. L., and Doniach, I. (1966). Pathological and clinical findings in a series of 67 cases of medullary carcinoma of the thyroid gland. J. clin. Path., 19, 103-113.

Williams, E. D., Morales, A. M., and Horn, R. C. (1968). Thyroid carcinoma and Cushing's syndrome: a report of two cases with a review of the common features of the 'non-endocrine' tumours associated with Cushing's syndrome. J. clin. Path., 21, 129-135.

\section{Addendum}

Since the manuscript was submitted Melvin, Miller, and Tashjian (1971) have reported 11 members of a family with medullary carcinoma of the thyroid who had raised plasma calcitonin levels after calcium infusion. Chief cell hyperplasia was found in nine cases. All were normocalcaemic but in six cases the plasma parathormone level was raised.

\section{Reference}

Melvin, R. E. W., Miller, H. H., and Tashjian, A. H., Jr. (1971). Early diagnosis of medullary carcinoma of the thyroid gland by means of calcitonin assay. New Engl. J. Med., 285, 11151120. 